\title{
Problems and Countermeasures in the Application of Network Teaching Platform for Ideological and Political Courses in Colleges and Universities
}

\author{
Song Yulan \\ Baicheng Normal University, Baicheng 137000, China \\ email: songyulan1977@163.com
}

\begin{abstract}
Keywords: Network Teaching Platform for Ideological and Political Courses in Colleges and Universities; Problems; Countermeasures
\end{abstract}

\begin{abstract}
With the continuous development of computer technology, the application of network teaching platform in colleges and universities is more and more widely, compared with the traditional teaching method, network teaching platform in time and the specific teaching mode are more flexible. The application of network teaching platform of Ideological and political course in universities was mainly investigated in this paper. Developing ideological and political courses in colleges and universities, on the one hand, is in order to better enhance the ideological and moral quality of students, on the other hand, can also play a certain role in regulating the students' words and deeds .With the application of network ideological and political course teaching platform, many problems, such as backward teaching concept, imperfect management system, information resource too single, have emerged and made this platform difficult to achieve the original effect in the application process. For the above problems, the corresponding research has been carried out and the concrete solutions were put forward.
\end{abstract}

\section{Introduction}

To carry out ideological and political courses in colleges is to ensure that students can not have an adverse impact on social factors, but also to comply with the requirements of the system in the daily life and study. Under the influence of computer technology and network technology, the specific curriculum development way also appeared certain transformations. The application of the network teaching platform for the ideological and political education of teachers and students. Students' learning provides a convenient time to become more flexible, teachers can better grasp the status of the students through the network platform [1]. At the same time, the platform in the application process also appeared many problems. These problems are likely to affect the ideological and political course of the development of effect. Not to the original teaching goal. This paper will put forward the actual on the basis of the analysis of these issues the improvement strategy.

\section{Application Status}

All industries cannot do without the assist of computer technology and network technology. The same is true for the education industry. Compared with the traditional teaching method, whether classroom teaching, classroom interaction, homework and examination process finally depend on the teachers. And the application of network teaching platform can reduce teachers the workload is fundamentally. From the function, the network teaching platform is the classroom, teacher-student interaction, a system of evaluation process are effectively combined, through the integration of these processes, the overall teaching efficiency can be further improved [2].

In the traditional teaching process, teaching practical mostly around textbooks and expanded. But on the ideological and political courses, students in the learning process will inevitably feel boring and lead to interest in learning, teaching effects. For college students, students can obtain from the network information very much, fixed in the textbooks is difficult compared with the network information level. To solve this problem, the network teaching platform on the basis of the original can greatly enrich the classroom resources, guarantee the students' interest in learning. 
From the teaching mode, the traditional teaching mode is mostly in a fixed time, fixed place to start, the student to teacher to explain the contents of the records are also more dependent on the lecture notes and classroom courseware. Obviously, this way will affect students' subsequent gaps. For this problem, the network teaching platform with time flexible, ready to playback, students can freely according to their own time to arrange the learning time. At the same time, when the students have problems in the learning process but also can quickly through the teaching content of network teaching platform prior to the review.

\section{Existing Problems}

The Management System Is Imperfect. Fundamentally speaking, the application of Ideological and political course network platform or in order to better the teaching of practical work carried out, but according to the current situation in China's colleges and universities and colleges have a large part of this work will pay attention to it, the construction of Ideological and political course network teaching platform is still in the primary stage. Students can learn by teaching platform to further reduce the content will lead to students' enthusiasm for application of this platform is reduced sharply. In a few colleges and universities, the campus network is applied only to the notification message, associated with the ideological and political course content is very little. In another part of the high school ideological and political course, although the construction of network teaching platform has been achieved to a certain extent, can provide certain information for students, but for the interaction between teachers and students, assessment and other aspects are not clearly reflected[3]. To solve these problems, we must further improve the network teaching Learning platform management system.

Interaction Efficiency Is Low. Compared to face-to-face teaching method, teaching process through the line is likely to have problems in the process of interaction for the ideological and political education. The function of network teaching platform, the platform should be provided to the students on the video, online answering, correcting homework, online examination and other functions. According to the present situation of the network. Most of the teaching platform is to do this. In the teaching process of thinking and political course, explain and answer line to the actual teaching effects. At the same time, the ideological and political course teachers, students to the teaching process of network teaching platform for teachers practical evaluation we have already mentioned above. And the application of the network teaching platform is the teaching process in order to assist the actual better, but such problems will not only on the actual learning process by the students Influence is also likely to cause teachers to find defects in the teaching process and Reform in a timely manner[4].

Platform Supervision Is Lax. Because the information on the Internet very much, college students are in adolescence, it is difficult to the authenticity of the information on the network to judge. These students are likely because of the impact of the information and go astray. On this basis, the university must be on the network information filtering in the process of constructing the network teaching platform. Avoid students affected by bad information in the network. To do this, we must strengthen supervision of Ideological and political course network teaching platform. According to the current situation in Colleges and universities, focusing on the platform management does not reach such effect. The students in the use of this platform in the process of learning is likely to be affected all kinds of ads and popups. On the other hand, in addition to network factors, because the supervision is not strict, the students in the application process is often not open the page even Not landing problems. These problems are the main factors that influence the ideological and political course network teaching platform to play its original role.

Resources Have no Timeliness. The ideological and political course teaching cannot do without the political news[5]. The advantage of application of network teaching platform for traditional teaching platform is also reflected at this point. But because the University's own mismanagement and attention is too low and other causes of the network teaching platform in the information update is difficult to meet the requirements of the ideological and political course for timeliness. The modern college students, the sources of information is various. If the ideological and political 
education network platform update does not live up to the demands of students in resources, students will naturally choose other channels to obtain information, resulting in the application of students on this platform lose interest. From the resources of the extensive degree, this platform is also difficult to the specific requirements to carry out ideological and political course. For college students, this part of the students problems in the learning process should be the first to discuss between the query and student information to solve these problems. The network teaching platform is the main channel for students to find relevant information. According to our data, students through this platform can get the most information for the strong academic nature, students of this kind of information in a contact would be interested in reading the phenomenon is not high, the other it may be difficult to understand too many terms and too deep content. Obviously, this problem will lead to further increase the workload of teachers, teaching efficiency in practice.

The Teaching Idea Is Backward. The teacher's teaching idea is the key factor to affect the actual teaching effect, but also for the college ideological and political courses[6]. We have already mentioned above, textbooks are excessively dependent on the traditional teaching method, the fixed time is too difficult to timely, gaps and other defects. To solve these problems, teachers of ideological and political courses must be introduced into the network teaching the platform in the actual teaching process. Some teachers due to their own teaching idea of curing, do not agree with this way of teaching writing, still continue to use the traditional teaching method, the teaching effect which leads to decreased. Also a part of the teachers for the application of this platform is to complete the task of school, not for the network teaching platform. Content on this platform, it is difficult to play its original role. For students, teachers' concept will also affect the students, if Teachers of Ideological and political courses so complacent, students are also difficult to realize the network teaching platform of the importance of learning.

\section{Resolution Strategy}

Improving the Management System. Management method for ideological and political education of university network teaching platform in detail, we must first be clear about one thing. This platform has in the actual teaching process function, from this perspective, the platform should have the main function is divided into information, education, communication three categories.

First of all, this platform should be able to provide all kinds of Ideological and political course and relevant information for students and teachers. This will ensure that students and teachers through this platform to quickly understand these messages and to expand exchanges with other users on the platform. For the actual management, responsible for the module management staff should be timely update of the content on the page, then select the related content of Ideological and political course for students to read and discussed. At the same time, we can also set up a week in the platform summary and monthly summary of plate, achieve information integration to help students better.

The network teaching platform should be able to assist the teachers of Ideological and political courses to better accomplish the task of teaching. For students, offline courses may be only 45-90 minutes, the students have problems in the course of learning when it is difficult for teachers to timely answer on the outside of the classroom. At this time, online answering and video content can be used as a good supplement. In the management of the content of this module, we should try to ensure the stability of the system, they can avoid Caton phenomenon during the visit.

From the communication sector, the ideological and political course has been regarded as a concept of students of curriculum in Colleges and universities. Students in the learning process rarely communicate with other students, it is difficult to find the natural course of charm, to further enhance the learning interest. To solve this problem, the AC section of the network teaching platform can be set a good solution to this problem. The main exchange can be self, and also by the management for the current hot spots to develop. In the process of management, management personnel should be responsible for the content of the communication management, not words should be timely to the spokesman of warning or directly delete.

Strengthen Supervision. If you want a better use of the school ideological and political course 
network teaching platform, we must set up the supervision program. So as to avoid the adverse effects of information on the Internet to students and ensure the operation efficiency of the whole system. First of all, for easy network teaching platform in advertising, pop and other problems, we can through the installation of filtering software certain to shield these contents, in order to ensure that the campus network environment. Secondly, the system of Caton to appear in the application process of the platform, not landing and other issues, we should be scheduled examination to determine the cause of problems and the maintenance of the system. Finally, the network teaching platform in University. The user visits the platform per day is very large. Therefore, the early construction in the platform, we have to solve this problem, advance the development of the big interview Ask for a measure of how the system works to avoid paralysis of the system because of the influx of students.

Enriching Teaching Resources. As I mentioned, the ideological and political course development cannot do without explanation for the current political content, teachers can use network teaching platform to complete. This paper mainly from the two aspects of timeliness and richness of information resources. The modern society is a highly information oriented society, the way people get information from traditional newspapers that TV news out, mobile phone and computer application for people to provide a great convenience. In view of this phenomenon, the network teaching platform must be able for the first time in the current hot politics more new, avoid because of the message in the platform of the lagged effect of student activity. On the breadth of information in terms of colleges and universities should avoid providing only the academic content of the phenomenon, the real-time information, the school can be the current affairs magazine as an extension of content for students to understand the knowledge for. For sexual content, schools can also provide video content to help students understand these content better

Change the Concept of Teaching. Ideological and political teachers should change the teaching concept. First, if the teachers on the network teaching platform of the acceptance is not high, the university can develop some training for the teachers. In this process, the training content should be mainly around the auxiliary function of network teaching platform on the actual teaching process. Secondly, if the teacher performance in the process of application is not positive or appear only in order to complete the task of the school, then the school should establish a system to control the situation, and through certain means to help encourage the teachers in the teaching application of this platform in the process.

\section{Conclusion}

In summary, the application of Ideological and political education network platform of university are teaching concepts backward, imperfect management system, information resource and so on. To solve these problems, this paper proposed in the third part the perfect management system, strengthen supervision, rich resources to solve the problem. In general, in the process of application of network teaching platform we should be in the students' actual experience and feedback in the first place, and to adjust the application strategy according to the situation of the students.

\section{References}

[1] Zhang Yunxia, Xie Zhenrong. Construction of Teaching Resources System and New Teaching Model of Ideological and Political Theory Course Based on Network Teaching Platform [J]. Guangxi Social Science. 2014 (12)

[2] Guan Xinhua, Wang Yue. Some Thoughts on the Network Reform of Ideological and Political Theory Course in Colleges and Universities as a Platform [J]. Research on Ideological and Political Education. 2014 (04)

[3] Zhao Rongchun, Zhang Wei, Fan Jie, Wei Dandan. Research on Problems and Countermeasures of Network Instruction Platform [J]. Science Mosaic. 2014 (07) 
[4] Feng Guofang, Zhao Yong. Research on the Effectiveness of Network Teaching of Ideological and Political Theory Courses [J]. Continued education research. 2015 (05)

[5] Yang Hongyun. Investigation and Reflection on the Construction of Network Teaching Platform for Ideological and Political Courses in Colleges and universities [J]. The Party Building and Ideological Education in Schools. 2015 (32)

[6] Shen Rui, Chen Shaoping. Investigation and Research on Website Construction of Ideological and Political Education in Universities [J].Journal of College Advisor. 2012 (05). 